UDC: 378: [57:005.336.2]

DOI: https://doi.org/10.24195/2414-4665-2017-8-11

\author{
Liliia Nikitchenko, \\ PhD (Candidate of Pedagogical Sciences), senior lecturer, \\ Department of Biology, \\ Vinnitsia State Pedagogical University named after Mykhailo Kotsiubynsky, \\ 32, Ostrozkoho Str., Vinnitsia, Ukraine
}

\title{
FORMING PROFESSIONAL COMPETENCE IN THE PROCESS OF TEACHING BIOLOGY STUDENTS
}

The development of the society puts forward new requirements to the professional training of higher educational institutions students. Today special attention is paid to the development of graduates' professional competence which is considered as a set of knowledge, abilities, and skills necessary for efficient performance of educational functions and harmonious development of a personality. The paper is aimed at theoretical grounding and experimental verification of pedagogical conditions contributing to the development of future Biology teachers' professional competence in the process of their professional training. Based on the results of the carried out experiment there have been determined the following conditions of efficient formation of Biology students' professional competence: providing the combination of theoretical material with practical activity in the process of professional training; activation of independent cognitive and research activity of students; providing the goals of professional training with personal meaning. The research outcomes have shown that purposeful use of the suggested pedagogical conditions improves the educational process and contributes to the efficient formation and development of future Biology teachers' professional competence, which has been confirmed by dynamics of mean values in the experimental group of students.

Keywords: professional competence, structure of competence, professional training, pedagogical conditions, future Biology teacher.

\section{Introduction}

The integration of Ukraine into the European environment is closely connected with the improvement of quality of national system of education. The development of the society puts forward new requirements to the professional training of university students. Nowadays special attention is paid to the development of specialists' professional competence, especially when it concerns future teachers. The modernization of education is impossible without fundamental changes in the teachers' work, and the transformations are possible only if the system of future teachers' professional training is improved.

Professional competence of a Biology teacher is a combination of his/her theoretical and practical occupation-related skills. Some scientists believe that professional training and professional competence should not be identified. Professional competence is a result of professional training. A competent person has relevant knowledge and skills which help him/her to make judgments about the occupation and perform his/her duties efficiently. Competence is usually understood as an integral personal quality based on knowledge and experience gained in the result of studying and socialization and focused on independent effective participation in it $[1 ; 4]$.

Some researchers consider professional competence as a set of knowledge, abilities and skills required for successful performance of functions of studying and harmonious development of a personality. A professionally competent teacher is the one who can solve educational challenges efficiently, achieve desired goals in the devel- opment of students' personalities; is open for selfdevelopment; is satisfied with the occupation [4, p. 17].

The issue of professional competence is studied by many foreign scientists as well. According to the carried out theoretical analysis, there is shift of emphasis to the requirements to modern professionals from formal factors of their qualification and education degree to social significance of their personal qualities in many European countries (England, Germany, France) [5; 7].

In Germany, the training process at higher educational institutions is focused on the development of cognitive and general intellectual skills, social and personal qualities, diligence, decision-making and communication skills, etc.

American scientists have developed a "competent worker" model which involves a set of personal and psychological qualities, for instance, independency, communicative skills, self-development skills. This model emphasizes personal self-development which is considered as a process of self-improvement, when a personality accepts the requirements and transforms them according to his/her level of consciousness, skills and needs [6, p. 165].

Under modern conditions significant transformations in the field of training future Biology teachers at higher educational institutions are taking place. Besides, there is a shift from traditional pedagogy to student-centered teaching.

Regardless of the great number of scientific research studies on the formation of future teachers' professional competence, the issue is still unsolved and relevant espe- 
cially concerning training Biology teachers in our country.

According to the literature review we distinguish the following key professional competence components: information competence providing IT skills; communication competence which is the ability to interact with other people, clearly express one's thoughts; subject competence which implies the knowledge of teaching tools; personal qualities important for every teacher - kindness, calmness, tolerance, reflection; as well as psychological competence which is the ability to use psychological means when organizing interaction in the educational environment $[2 ; 6]$.

The carried out scientific literature review has helped us to distinguish the key components of future Biology teachers' professional competence: theoretical knowledge - necessary subject knowledge which increase teacher's confidence in the correctness of professional activities performance, contribute to the further professional development in the practical aspect because practical activity is impossible without theoretical knowledge; practical skills - teachers' practical actions based on occupation-related knowledge; personal qualities - kindness, tolerance, reflection. In our opinion, it is these components which should be analyzed and controlled in the process of future Biology teachers training. Besides, they should be analyzed by a teacher himself/herself for determining of his/her competence level.

The paper aims to check pedagogical conditions of forming future Biology teachers' professional competence in terms of studying at higher educational institutions. solved:

According to the aim, the following tasks should be

- evaluate the professional competence components' maturity in Biology students;

- define pedagogical conditions contributing to the formation of future Biology teachers' professional competence and check their efficiency.

\section{Research Methods}

The experiment aimed at examining the efficiency of pedagogical conditions into the process of training future Biology teachers' professional competence was held at Vinnitsia State Pedagogical University named after Mykhailo Kotsiubynsky and involved 48 students majoring in "Biology" and "Biology and Chemistry" divided into control $(n=23)$ and experimental $(n=25)$ groups. The respondents of the EG were taught accounting for the suggested pedagogical conditions, and CG - without them.

The levels of the respondents' professional competence maturity were examined by means of the following methods:

- The theoretical component (students' theoretical knowledge) was examined by means of a set of developed testing tasks. We have chosen testing because it provides an opportunity to check students' academic achievements simultaneously in various topics and units of the curricu- lar; to evaluate students' knowledge objectively, and to create equal conditions for all participants;

- A number of practical tasks were suggested to students in order to evaluate the level of their practical skills (for example, recognizing plants or animals, making herbariums, conducting experiments, etc.).

- Methods: Bass Orientation Inventory, A. Rean's "Motivation of Success and Fear of Failure Inventory", self-assessment of professional qualities were used for examining the level of the respondents' personal qualities.

- Expert's evaluation and observation method were used in order to assess the respondents' creative potential.

The verification of the groups' homogeneity was carried out using Student's t-test and Pearson's chi-squared test [3, p. 98].

There are two research hypotheses ( $\mathrm{H} 0$ and $\mathrm{H} 1) . \mathrm{H} 0$ implies that there is no significant difference between the indicators of professional competence maturity levels in EG and CG. In order to check it we used Pearson's chisquared test after carrying out the experiment.

Pedagogical conditions contributing to the development of Biology students' professional competence

Based on the results of the carried out experiment we have determined the pedagogical conditions which contribute to efficient formation of future Biology teachers' professional competence:

- providing the combination of theoretical material and practical activity in the educational process;

- activating independent research activity of students;

providing the goals of professional training with personal meaning.

Let us consider these conditions and describe them.

The combination of theoretical and practical training of future Biology teachers makes professional training more efficient, and contributes to the formation of students' professional competence.

The unity of theoretical knowledge and practical skills provide a new aspect of professional training, combines new practical achievements and working experience, makes it possible to achieve the desired goals of teaching. A future Biology teacher should have mature enough theoretical and practical skills for designing his/her own individual creative teaching technology.

Students' independent research activities are a significant factor in the process of professional competence formation as they help to gain necessary knowledge and skills. In order to provide independent research activities of students a teacher should create didactic conditions contributing to timely and successful performance of suggested research works.

Student-centered approach in training provides such an organization of interaction between a teacher and students when the individual peculiarities are fully applied, it provides an opportunity to develop every student's professional competence, reveal and use individual practical 
experience, develop stable desire for self-study and professional self-development.

\section{Research Results and their Discussion}

The results of the carried out empirical research before implementing the above listed pedagogical conditions are presented in Table 1.

Table 1.

Levels of Biology Students' Professional Competence Maturity (\%)

\begin{tabular}{|c|c|c|c|c|c|c|c|c|}
\hline \multirow{2}{*}{$\begin{array}{c}\text { Professional Competence Compo- } \\
\text { nents }\end{array}$} & \multicolumn{9}{|c|}{ Levels } \\
\cline { 2 - 9 } & \multicolumn{2}{|c|}{ low } & \multicolumn{2}{|c|}{ medium } & \multicolumn{3}{c|}{ high } & \multicolumn{2}{c|}{ creative } \\
\cline { 2 - 9 } & CG & EG & CG & EG & CG & EG & CG & EG \\
\hline Theoretical knowledge & 39.08 & 41.25 & 42.52 & 43.61 & 10.90 & 11.90 & 1.25 & 1.38 \\
\hline Practical skills & 38.56 & 44.65 & 45.43 & 44.55 & 14.67 & 13.77 & 0.65 & 1.00 \\
\hline Personal qualities & 39.54 & 48.72 & 42.56 & 41.14 & 12.00 & 12.01 & 0.45 & 0.33 \\
\hline Mean values & 39.31 & 44.87 & 43.50 & 43.1 & 12.52 & 12.56 & 0.78 & 0.90 \\
\hline
\end{tabular}

Table 1 shows that the level of the respondents' professional competence maturity before implementing the suggested pedagogical conditions into the educational process is almost the same in the control and experimental groups.
The generalized results of the maturity of the respondents' professional competence components after the implementation of the technique are presented in Table 2.

Levels of Biology Students' Professional Competence Maturity (\%)

\begin{tabular}{|c|c|c|c|c|c|c|c|c|}
\hline \multirow{2}{*}{$\begin{array}{c}\text { Professional Competence Compo- } \\
\text { nents }\end{array}$} & \multicolumn{9}{|c|}{ Levels } \\
\cline { 2 - 9 } & \multicolumn{2}{|c|}{ low } & \multicolumn{2}{|c|}{ medium } & \multicolumn{3}{c|}{ high } & \multicolumn{2}{c|}{ creative } \\
\cline { 2 - 9 } & CG & EG & CG & EG & CG & EG & CG & EG \\
\hline Theoretical knowledge & 40.27 & 34.09 & 44.98 & 28.00 & 13.15 & 30.44 & 2.05 & 7.97 \\
\hline Practical skills & 41.23 & 34.10 & 46.32 & 26.50 & 13.16 & 29.89 & 2.03 & 8.55 \\
\hline Personal qualities & 39.74 & 34.14 & 45.20 & 27.10 & 13.13 & 31.05 & 2.04 & 8.16 \\
\hline Mean values & 40.41 & 34.10 & 45.50 & 27.20 & 13.15 & 30.45 & 2.04 & 8.25 \\
\hline
\end{tabular}

As we can see in Table 2, after conducting the experiment, the Biology students of the experimental group have reached significant positive changes in the maturity of the components of their professional competence as compared to the control group, which was taught according to traditional methods without implementing the developed pedagogical conditions.

According to the indices of the creative level, the number of students of the control group has increased from $0.78 \%$ to $2.04 \%$, which makes $1.26 \%$, and from $0.9 \%$ to $8.25 \%$ (which makes $6.09 \%$ ) - in the experimental one.

The number of students with the high level of professional competence maturity has increased in the CG from $12.52 \%$ to $13.15 \%$ (which makes $0.63 \%$ ) and in the EX - from $12.56 \%$ to 30.45 (which makes $17.89 \%$ ), which is indicative of better results in the EG.
The number of students with the medium level of professional competence maturity has not actually changed in the control group. On the contrary, in the experimental group, we can see the significant decrease of the number of respondents with the medium level - from $41.10 \%$ to $27.20 \%$, which makes $15.9 \%$. According to the indices of the low level of the respondents' professional competence, there were no significant changes in the CG. In the EG, we can see the significant decrease of the number of students with the low level of professional competence maturity - from $44.87 \%$ to $34.10 \%$.

We can conclude that the suggested pedagogical conditions do contribute to the formation and development of future Biology teachers' professional competence according to the positive results of the development of its components.

The dynamics of the efficiency of the experimental technique is presented in Figure 1. 


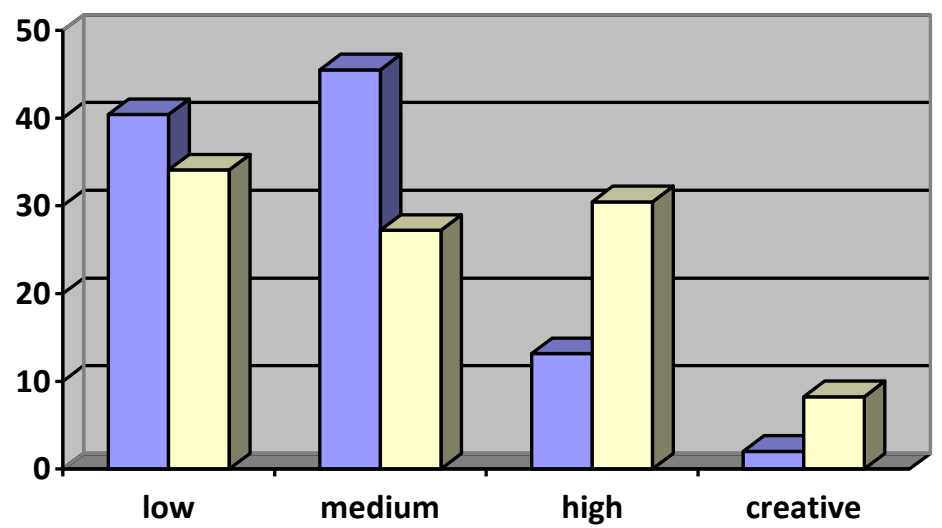

Fig. 1. The dynamics of indices of the respondents' professional competence maturity before and after implementing the suggested pedagogical conditions into the educational process (\%)

In order to observe if there is significant difference between the indicators of professional competence maturity levels in EG and CG we refer to Table 3.

Table 3.

\begin{tabular}{|c|c|c|c|c|c|}
\hline $\begin{array}{c}\text { № } \\
\text { interval }\end{array}$ & $\begin{array}{c}\text { Relative ratio } \\
f_{\text {emp }, \%}\end{array}$ & $\begin{array}{c}\text { Relative fre- } \\
\text { quency } \\
f_{\text {crit }}, \%\end{array}$ & $f_{\text {emp }}-f_{\text {crit }}$ & $\left(f_{\text {emp }}-f_{\text {crit }}\right)^{2}$ & $\frac{\left(f_{\text {emp }}-f_{\text {crit }}\right)^{2}}{f_{\text {crit }}}$ \\
\hline \hline 1 & 34.10 & 40.41 & -6.31 & 39.8161 & 4.05 \\
\hline 2 & 27.20 & 45.50 & -18.3 & 344.25 & 0.25 \\
\hline 3 & 30.45 & 13.15 & 17.3 & 299.29 & 1.86 \\
\hline \hline & 5.25 & 0.94 & 4.31 & 18.5761 & 1.79 \\
\hline \hline Total & $100 \%$ & $100 \%$ & & & $X_{\text {emp }}^{2}=7.95$ \\
\hline
\end{tabular}

For the degree of freedom $n-1=3$ with significance point $\alpha=0.05$ we find out that $X_{e m p}^{2}=7.95$. Therefore, $X_{e m p}^{2}>X_{\text {crit }}^{2}$

Thus, the H0 is declined, and $\mathrm{H} 1$ is accepted, which means that the differences between the obtained indicators are not accidental (with $95 \%$ probability) which justifies the efficiency of the carried out experiment.

As we can see, the comparison of the results in the CG and EG means that the suggested pedagogical conditions contribute to the development of future Biology teachers' professional competence.

\section{REFERENCES}

1. Kutsak, L. V. (2010). Definitsiia poniattia «kompetentnist» ta «kompetentsiia» $\mathrm{u}$ naukovykh doslidzhenniakh [The definition of the concepts "competence" and "competency" in reseaech studies]. Suchasni informatsiini tekhnolohii ta innovatsiini metodyky navchannia $v$ pidhotovtsi fakhivtsiv: metodolohiia, teoriia, dosvid, problemy : zb. nauk. pr. - Modern information technologies and innovative techniques on training specialists: meth-

\section{Conclusion}

Thus, the research outcomes has shown that the purposeful application of the developed pedagogical conditions in the process of training Biology students qualitatively changes the educational process, increases the efficiency of forming their professional competence, which has been confirmed by the dymanics of mean values.

The carried out research does not cover all aspects of the issue. The development of the system of future Biology teachers' professional training system using modern innovative technologies is a relevant and interesting direction of further investigations.

ods, theory, experience, chellenges: collection of scientific works, 26, 344-348. Kyiv-Vinnytsia: TOV firma «Planer» [in Ukrainian].

2. Pelaheichenko, V. (2009). Kliuchovi komponenty kompetentnosti vchytelia [Key components of teacher's competence]. Vidkrytyi urok: rozrobky, tekhnolohii, dosvid - Open lesson: developments, technology, experience, 2, 55-59 [in Ukrainian]. 
3. Herasymenko, S. S., Holovach, A. V., Yerina, A. M. (2000). Statystyka: pidruchnyk [Statistics: textbook]. Kyiv: KNEU [in Ukrainian].

4. Pometun, O. I. (2004). Teoriia ta praktyka poslidovnoi realizatsii kompetentnisnoho pidkhodu v dosvidi zarubizhnykh krain [Theory and practice of staged realization of competence-based approach in foreign countires' experience]. Kompetentnisnyi pidkhid u suchasnii osviti: svitovyi dosvid ta ukrainski perspektyvy : biblioteka $z$ osvitnoi polityky - Competence based approach in modern education: world experience and Ukrainian perspectives:

\section{ЛІТЕРАТУРА}

1. Куцак Л. В. Дефініція поняття «компетентність» та «компетенція» у наукових дослідженнях / Л. В. Куцак // Сучасні інформаційні технології та інноваційні методики навчання в підготовці фахівців: методологія, теорія, досвід, проблеми : зб. Наук. Пр. ; редкол. : І. А. Зязюн (голова) та ін. - Київ-Вінниця : ТОВ фірма «Планер», 2010. - [вип. 26]. - С. 344-348.

2. Пелагейченко В. Ключові компоненти компетентності вчителя / В. Пелагейченко // Відкритий урок: розробки, технології, досвід. - 2009. - № 2. - С. 55-59.

3. Статистика : підручник / [C. С. Герасименко, А. В. Головач, А. М. Єріна та ін.] ; за ред. Д-ра екон. Наук С. С. Герасименко. - К. : КНЕУ, 2000. - 497 с.

4. Пометун О. І. Теорія та практика послідовної реалізації компетентнісного підходу в досвіді зарубіжних країн / О. І. Пометун // Компетентнісний library in educational policy (pp. 16-26). O. V. Ovcharuk (Ed.). Kyiv: K.I.S. [in Ukrainian].

5. Stoof, Angela. What is a competency? Constructivist approach as a way out of the confusion. Rertieved from: http://www.hr-portal.ru/ node/348 [in English].

6. Short, E. C. Gleanings and possibilities. In E. C. Short (Ed.), Competence: inquiries into its meaning and acquisition in educational settings. -Lanham : University Press of America, 1984. - P. 161-180. [in English].

7. Wharfe, L. (1991). A new approach to teacher training. Higher Education News, 13, 10-12 [in English].

підхід у сучасній освіті: світовий досвід та українські перспективи : бібліотека з освітньої політики ; під заг. Ред. О. В. Овчарук.- К. : «К.І.С.», 2004. - С. 16-26.

5. Stoof Angela. What is a competency? Constructivist approach as a way out of the confusion [Електронний ресурс] / Angela Stoof, Rob L. Martens, Jeroen J. G. Van Merrienboer. - Режим доступу : http://www.hr-portal.ru/ node/348.

6. Short E. C. Gleanings and possibilities. In E. C. Short (Ed. ), Competence: inquiries into its meaning and acquisition in educational settings. -Lanham : University Press of America, 1984. - P. 161-180.

7. Wharfe L. A new approach to teacher training / L. Wharfe // Higher Education News. - 1991. - № 13. P. 10-12.

\section{Лілія Олександрівна Нікітченко, кандидат педагогічних наук, стариий викладач кафедри біології, Вінницький державний педагогічний університет імені Михайла Коиююбнського, вул. Острозького, 32, м. Вінниия, Украӥна}

\section{ФОРМУВАННЯ ПРОФЕСІЙНОӤ КОМПЕТЕНТНОСТІ У ПРОЦЕСІ ПІДГОТОВКИ МАЙБУТНІХ УЧИТЕЛІВ БІОЛОГІЇ}

Розвиток суспільства ставить перед вищою освітою нові вимоги до підготовки випускників педагогічних закладів. На сьогоднішній день особлива увага приділяється формуванню професійної компетентності. Науковці розглядають професійну компетентність як сукупність знань, умінь, навичок, які потрібні для успішного виконання функцій навчання, виховання, гармонійного розвитку особистості. Мета статті полягає у визначені, теоретичному обгрунтуванні та експериментальній перевірці педагогічних умов формування професійної компетентності майбутніх учителів біології у процесі підготовки. На основі результатів проведеної експериментальної роботи було визначено умови успішного формування професійної компетентності майбутніх вчителів біології в процесі підготовки: забезпечення поєднання теоретичного матеріалу з практичною діяльністю в процесі професійної підготовки майбутніх учителів біології; активізація самостійної пізнавально-дослідницької діяльності студентів; надання цілям професійної підготовки в процесі навчання особистісного смислу. Під час дослідження було використано такі методи: теоретичні, емпіричні, статистичні методи математичної обробки наукових даних. Результати дослідження засвідчили, що цілеспрямоване застосування у навчальному процесі запропонованих педагогічних умов якісно змінює процес навчання, підвищує ефективність формування професійної компетентності майбутніх учителів біології. Краща результативність формування професійної компетентності майбутніх учителів біології в експериментальній групі підтверджується динамікою середніх показників.

Ключові слова: професійна компетентність, структура компетентності, професійна підготовка, педагогічні умови, майбутній учитель біології.

Submitted onn June, 15, 2017

Reviewed by Doctor of Pedagogy, prof. O. Akimova 